\title{
The Implications of the 4 C's of Supply Chain Network Interaction Strategies for Cost Information Visibility and Network Profitability - An Integrative Model
}

\author{
Jyotirmoyee Bhattacharjya ${ }^{1, *}$, David Walters ${ }^{1}$, and Charlotte Newton ${ }^{2}$ \\ ${ }^{1}$ Institute of Transport and Logistics Studies, The University of Sydney, Newtown Campus, \\ 144 Burren Street, Newtown, NSW 2042, Australia \\ ${ }^{2}$ Northeast Europe IBM Basel \\ \{jyotirmoyee.bhattacharjya, david.walters\} esydney.edu.au, \\ charlotte.newton@uk.ibm.com
}

\begin{abstract}
The globalization of supply and demand has resulted in increasingly complex supply chain interaction strategies across different industries. Since the different interaction strategies are associated with different types of interdependence between partners, the impact of these strategies on cost information visibility across a supply chain network merits further investigation. The importance of cost information visibility lies in the fact that a firm's internal costs can often depend on the business processes of other members within their network. The paper uses a multi-theoretical perspective to develop an integrative model of the impact of the different dimensions of interaction strategies on cost information visibility and profitability in supply chain networks.
\end{abstract}

Keywords: Coordination, collaboration, interdependence, cost information visibility, profitability.

\section{Introduction}

Organizations increasingly operate within globally distributed complex supply chain networks and employ different interaction strategies due to their interdependence on other members. The configurations for these interaction strategies have been described by 4 C's: communicative, coordinated, collaborative, co-opetitive [7]. Although these $4 \mathrm{C}$ 's have been defined variously in the literature, but their underlying concept of interdependence, can potentially have a significant impact on cost information visibility for members in a supply chain network. Many business decision-makers struggle with limited supply chain cost visibility and an understanding of how the costs of other members in their network affect their own costs [45]. While information technologies has been shown to positively influence general information visibility in a supply chain [e.g., 48] the relational factors that

\footnotetext{
* Corresponding author.
} 
specifically influence cost information visibility need further investigation. This paper attempts to provide some insight in this context.

\section{Theoretical Background}

The interactions between companies in a supply chain network are complex and may involve the flow of physical goods [2], finances [3] and information [4] across organizational boundaries. A number of issues add to the complexity of these interactions and pose challenges for researchers: time, interdependence, relativity, jointness and subjective interpretation [1]. The nature of interactions between companies at a given time may be an outcome of their previous interactions, current interactions with others and anticipation of future interactions.

\subsection{The 4 C's of Configuration in Network Based Interaction Strategies}

Fiske [5] identified four relational forms as fundamental to most forms of social interactions: market pricing, authority ranking, equality matching and communal sharing. The market pricing relational form is one based on socially meaningful rates such as prices, wages and rents. Authority ranking relationships involve people in asymmetric positions in a hierarchy. Equality matching relationships are those in which people keep track of the emerging difference between participants and what is required to restore the balance. Communal sharing involves people treating a group as equivalent to the given domain. Building on this conceptualization of relational forms [5], Sheppard and Sherman [6] identified four forms of interdependence based on depth (i.e., intensity) and form (i.e., the directionality of dependence): shallow dependence, deep dependence, shallow interdependence and deep interdependence. The term dependence implies that the nature of dependency is unidirectional. Shallow dependence involves a transfer of responsibility from one party to another and relates to Fiske's market pricing relational form. Shallow interdependence involves parties coordinating their behavior in order to achieve their objectives and is associated with the equality matching relational form. Deep dependence relates to the authority ranking relational form and involves a principal-agent type of relationship with knowledge based asymmetry. Deep interdependence involves parties having a greater and wider-ranging reliance on each other and is associated with the communal sharing relational form. Based on these ideas of relational form and depth and form of interdependence, Lejeune and Yakova [7] distinguished between four types of supply chain configurations. The four configurations are as follows:

- Communicative - This type of configuration ([7],[8],[9],[10]) is related to the market pricing relational form and characterized by shallow dependence. Collaboration only takes place at an inter-functional level within each company in the network.

- Coordinated - This configuration ([7],[13],[14],[15]) is related to the authority ranking relational form and characterized by deep dependence. These types of supply chain networks are dominated by a lead organization ([11],[12],[16],[17]) and exhibit a combination of both reliability and deterrent-based trust [7]. 
- Collaborative: This configuration relates to the equality matching relational form and is characterized by shallow interdependence. Trust in this context is reliability, competency and goodwill (openness) based [8] and the decisionmaking process is dyadic, parity-based and centralized ([18],[19]).

- Co-opetitive: This configuration ([20],[21],[24],[25]) relates to the communal sharing relational form and is marked by deep interdependence. It is viewed as an example of lateral collaboration in which competitors share resources and private information [22]. Trust in co-opetitive supply chains is based on reliability, competency and goodwill (openness and benevolence). Unlike collaborative supply chains co-opetitive ones exhibit both components of goodwill trust - openness and benevolence ([23],[9]).

This classification of configurations, though insightful, does not explicitly take into account the evolving nature of relationships in the network over time and the dynamic nature of resources and capabilities which form the basis of interdependence as suggested by [1]. Resource dependency theory and the relational view provide some insight in this context.

\subsection{Resources and Capabilities in Supply Chain Networks}

Relational View. This perspective [26] extended the arguments presented by the resource based view of the firm ([27], [28], [29]) to introduce the notion that the critical resources of a firm may lie beyond organizational boundaries and may be embedded in interorganizational routines and resources. Some potential sources of interorganizational competitive advantage are identified by this view: relation-specific assets, knowledge sharing routines, complementary resources/capabilities and effective governance [26]. Time can play an important role in the context of these sources of relational rent. Supply chain members can combine capabilities or resources which then coevolve over time and become difficult to imitate, thus becoming a source of competitive advantage. Informal safeguards, such as goodwill trust and reputation may also take considerable time to develop and are also subject to opportunity for abuse [30].

Resource Dependency Perspective. This view focuses on how organizations acquire resources and thereby affect their power relationships with other firms ([31], [32]). It is based on three assumptions [33]. Firstly, organizations are assumed to comprise of external and internal coalitions arising from social exchanges which are designed to influence behavior [32]. Secondly, the environment contains critical resources and poses variability and complexity during acquisition from other firms [34] which can be reduced by forming different types of linkages [33]. Thirdly, organizations work towards acquiring control over resources that minimize their dependence on other firms and maximize the dependence of other firms on themselves and attaining either objective could affect an organization's power [31]. For example, Millenium Pharmaceuticals, a company that had in the past relied quite heavily on partnerships, began to undertake acquisitions in the late 1990's in order to expand its downstream presence [35] but was subsequently acquired by the Takeda Group in 2008 [36]. This third assumption, therefore, points towards the dynamic nature of configuration in supply chain network interaction strategies. 


\section{Antecedents and Outcomes of Cost Information Visibility - An Emergent Model}

Total Productivity and Profitability. The term productivity means different things to different people. This paper adopts the definition suggested by Craig and Harris [37]. According to this definition, the total productivity of a firm is the ratio of the total output in dollars and the sum of the labor input, capital input, raw material and purchased parts and other miscellaneous goods and services (also in dollars). Productivity is positively related to the profitability of a firm ([38],[39]) and has been measure in terms of return on equity (ROE), the ratio of a firm's net income and the shareholders' total equity [39]. While the literature suggests that the business landscape is one of networks competing against each other (e.g. [40]), there is little attempt to describe profitability from a network perspective. In attempting to address this issue, this paper defines network profitability as an index which is the sum of ROE's of all firms in the supply chain network for a given configuration at a given time.

Cost Information Visibility. The issue of cost information visibility poses many challenges in a supply chain context, including supplier guile and the lack of managerial experience in sharing sensitive cost information with other supply chain members [41]. Use of archaic cost allocation processes [42], different definitions of overhead costs [43], managerial awareness of weakness in internal cost systems, perception of cost management as an internal affair, lack of agreement amongst supply chain members regarding which costs to report, levels of dependence and trust [44] have all been argued to inhibit cost transparency. The visibility of cost information across a firm's supply chain network can provide opportunities for driving cost reductions and enabling higher performance as many internal costs of a firm can result from the business practices and behavior of other members of the supply chain network [45]. Such improvement in performance could be manifested as higher productivity and profitability for an organization. The model in Figure 1 considers both a buyer's perception of a supplier's cost visibility and vice versa.

Dimensions of Network Interaction Strategy. The four types of network configurations (communicative, coordinated, collaborative and co-opetitive) have been differentiated in the literature in terms of form (trust and decision-making) and depth (information sharing and goal congruence) of interdependence [7]. It has also been suggested that practitioners may have a different perspective on interorganizational relationships than researchers [46,47] and network members may themselves subjectively interpret the actions of other members [1]. Given the dynamic and complex nature of interfirm relationships, different configurations may even coexist within the same network and the distinction between the configurations may not be as clear. Therefore, rather than focusing on the specific configurations, the model in Figure 1 considers the perceived overall nature of the two dimensions (form of interdependence and depth of interdependence) based on which these configurations are distinguished and their influence on cost visibility. It also assumes that there may be differences in perceptions between buyers and suppliers with regards to both form and depth of interdependence. 


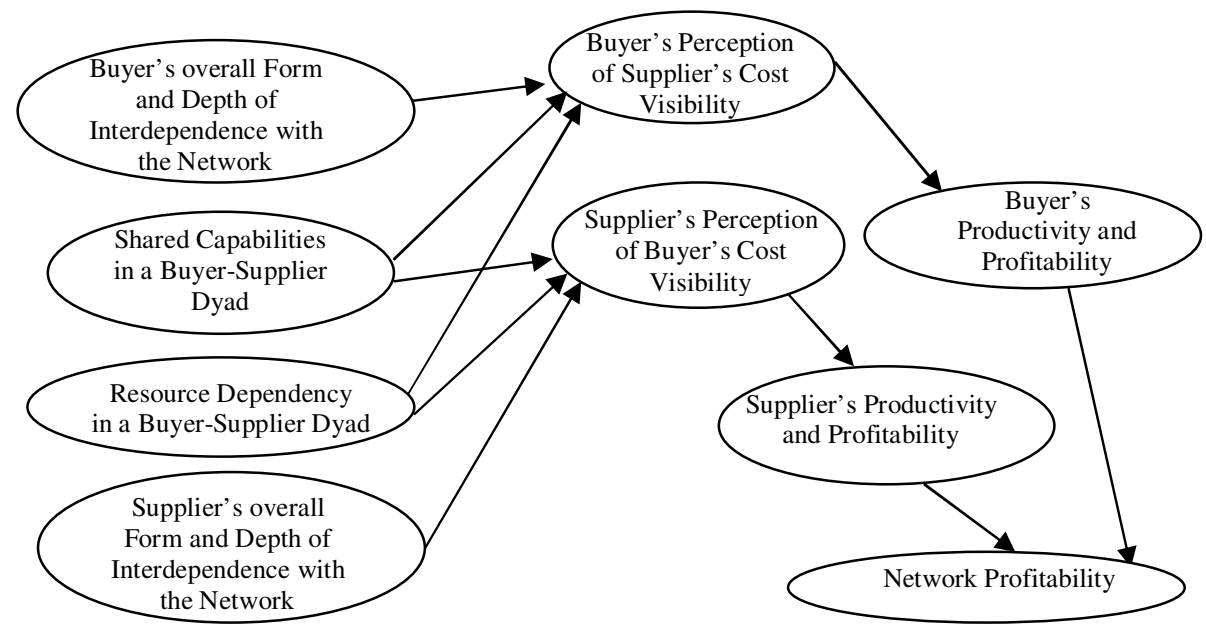

Fig. 1. The Influence of Network and Dyad Level Interdependencies on Perceived Cost Information Visibility and Profitability

Capabilities and Resources in Relationships. Interdependence in interorganizational relationships generally arises from different firms combining their resources and capabilities [26] or from the dependency of one firm on the resources of another ([31], [32]). These bonds evolve over time and may impact upon the perceived cost information visibility. The integrative model is illustrated in Figure 1.

\section{Discussion}

The paper presents an integrative model of the antecedents and outcomes of cost information visibility in a supply chain network. The model is in early stages of development and does not incorporate broader environmental factors like national cultures and regulatory requirements which could vary across a global supply chain network. It also does not include intra-organizational factors such as leadership that might have significant influence on supply chain decisions. It should also be noted that theory often lags business practice and misses the organic nature of change in the business landscape. These issues suggest that the model could be further refined based on input from supply chain practitioners and future research could identify how cost information visibility evolves over time based on changing antecedents and verify the impact of improved cost information visibility on firm and network profitability.

\section{References}

1. Ford, D., Håkansson, H.: The Idea of Business Interaction. The IMP J. 1, 4-20 (2005)

2. Stevens, G.C.: Successful Supply Chain Management. Management Decision 28, 25-30 (1990) 
3. Mabert, V.A., Venkatraman, M.A.: Special Research Focus on Supply Chain Linkages: Challenges for Design and Management in the 21st Century. Decision Sciences 29, 537550 (1998)

4. Lee, H.L., Padmanabhan, V., Whang, S.: Information Distortion in Supply Chain: The Bullwhip Effect. Management Science 43, 546-558 (1997)

5. Fiske, A.P.: Relativity within Moose ("Mossi") culture: four incommensurable models for social relationships. Ethos 18, 180-204 (1990)

6. Sheppard, B.H., Tuchinsky, M.: Interfirm relationships: a grammar of pairs. In: Cummings, L.L., Staw, B.M. (eds.) Research in Organizational Behavior, vol. 18, pp. 331373. JAI Press, Greenwich (1996)

7. Lejeune, M.A., Yakova, N.: On characterizing the $4 \mathrm{C}$ 's in supply chain management. Journal of Operations Management 23, 81-100 (2005)

8. Handfield, R.B., Nichols Jr., E.L.: Introduction to Supply Chain Management. PrenticeHall, Upper Saddle River (1999)

9. Stuart, F.I., McCutcheon, D.M.: The manager's guide to supply chain management. Business Horizons 43, 23-44 (2001)

10. Villa, A.: Introducing some supply chain management problems. International Journal of Production Economics 73, 1-4 (2001)

11. Alvarado, U.Y., Kotzab, H.: Supply chain management: the integration of logistics in marketing. Industrial Marketing Management 30, 183-198 (2001)

12. García-Dastugue, S.J., Lambert, D.M.: Internet-enabled coordination in the supply chain. Industrial Marketing Management 32, 251-263 (2003)

13. Käser, P.A.W., Miles, R.E.: Understanding knowledge activists' successes and failures. Long Range Planning 35, 9-28 (2002)

14. Cox, A., Sanderson, J., Watson, G.: Supply chains and power regimes: toward an analytic framework for managing extended networks of buyer and supplier relationships. Journal of Supply Chain Management 37, 28-35 (2001)

15. Kelley, H.H., Thibaut, J.W.: Interpersonal Relations: A Theory of Interdependence. Wiley, New York (1978)

16. Dyer, D.H., Ouchi, W.G.: Japanese-style partnerships: giving companies a competitive edge. Sloan Management Review, 51-63 (1993)

17. Fung, V.K., Fung, W.K., Wind, Y.: Competing in a Flat World: Building Enterprises for a Borderless World. Wharton School Publishing, Upper Saddle River (2008)

18. Grandori, A., Soda, G.: Inter-firm networks: antecedents, mechanisms and forms. Organization Studies 16, 183-214 (1995)

19. Clark, T.H., Lee, H.G.: Electronic commerce and supply chain management. Information Technology and Management 1, 85-105 (2000)

20. Brandenburger, A.M., Nalebuff, B.J.: Co-opetition. Doubleday, New York (1996)

21. Bengtsson, M., Kock, S.: "Coopetition" in business networks - to compete and cooperate simultaneously. Industrial Marketing Management 29, 411-426 (2000)

22. Simatupang, T.M., Sridharan, R.: The collaborative supply chain. International Journal of Logistics Management 13, 15-30 (2002)

23. Strickland, L.H.: Surveillance and trust. Journal of Personality 26, 200-215 (1958)

24. Grahovac, J., Chakravarty, A.: Sharing and lateral transshipment of inventory in a supply chain with expensive low-demand items. Management Science 47, 579-594 (2001)

25. Greis, N.P., Kasarda, J.D.: Enterprise logistics in the information era. California Management Review 39, 55-78 (1997)

26. Dyer, J.H., Singh, H.: The Relational View: Cooperative Strategy and Sources of Interorganizational Competitive Advantage. Academy of Management Review 23, 660 679 (1998) 
27. Barney, J.: Firm resources and sustained competitive advantage. Journal of Management 17, 99-120 (1991)

28. Rumelt, R.P.: How much does industry matter? Strategic Management Journal 12, 167185 (1991)

29. Wernerfelt, B.: A resource-based view of the firm. Strategic Management Journal 5, 171180 (1984)

30. Granovetter, M.: Economic action and social structure: The problem of embeddedness. American Journal of Sociology 91, 481-510 (1985)

31. Pfeffer, J.: Power in organizations. Pitman, Marshfield (1981)

32. Pfeffer, J., Salancik, G.: The external control of organizations. Harper and Row, New York (1978)

33. Ulrich, D., Barney, J.B.: Perspectives in organizations: Resource dependence, efficiency, and population. Academy of Management Review 9, 471-481 (1984)

34. Pfeffer, J.: The micropolitics of organizations. In: Meyer, M.W., Associates (eds.) Environments and organizations, pp. 29-50. Jossey-Bass, San Francisco (1978)

35. Champion, D.: Mastering the Value Chain - An Interview with Mark Levin of Millennium Pharmaceuticals. Harvard Business Review, 108-115 (2001)

36. Takeda Pharmaceutical Company Limited, Takeda Completes Acquisition of Millennium (2008), http: / /www.takeda.com/press/article_29939.html

37. Craig, C.E., Harris, R.C.: Total Productivity Measurement at the Firm Level. Sloan Management Review 14, 13-29 (1973)

38. Anderson, E.W., Fornell, C., Rust, R.T.: Consumer satisfaction, productivity, and profitability: Differences between goods and services. Marketing Science 16, 311-329 (1997)

39. He, Y.-Q., Chan, L.-K., Wu, M.-L.: Balancing productivity and consumer satisfaction for profitability: Statistical and fuzzy regression analysis. European Journal of Operations Research 176, 252-263 (2007)

40. Lambert, D.M., Cooper, M.C.: Issues in supply chain management. Industrial Marketing Management 29, 65-83 (2000)

41. Lamming, R., Jones, O., Nicol, D.: Transparency in the Value Stream from Open-Book Negotiation to Cost Transparency. In: Hines, R., Lamming, R., Jones, D., Cousins, P., Rich, N. (eds.) Value Stream Management. Pearson Education Limited, Harlow (2000)

42. Cokins, G.: Activity-Based Cost Management: An Executive's Guide. John Wiley \& Sons, New York (2001)

43. Munday, M.: Buyer-Supplier Partnerships and Cost Data Disclosure. Management Accounting 70, 28-35 (1992)

44. Kajuter, P., Kulmala, H.I.: Open-Book Accounting in Networks - Potential Achievements and Reasons for Failures. Management Accounting Research 16 (2005)

45. Pohlen, T.L., Klammer, T.P., Cokins, G.: The Handbook of Supply Chain Costing. Council of Supply Chain Management Professionals, Lombard, Illinois (2009)

46. Porac, J.F., Thomas, H., Baden-Fuller, C.: Competitive groups as cognitive communities: the case of Scottish knitwear manufacturers. Journal of Management Studies 26, 397-415 (1989)

47. Reger, R.K., Huff, A.: Strategic groups: a cognitive perspective. Strategic Management Journal 14, 103-123 (1993)

48. Wang, E.T.G., Wei, H.-L.: Interorganizational Governance Value Creation: Coordinating for Information Visibility and Flexibility in Supply Chains. Decision Sciences 38, 647-674 (2007) 